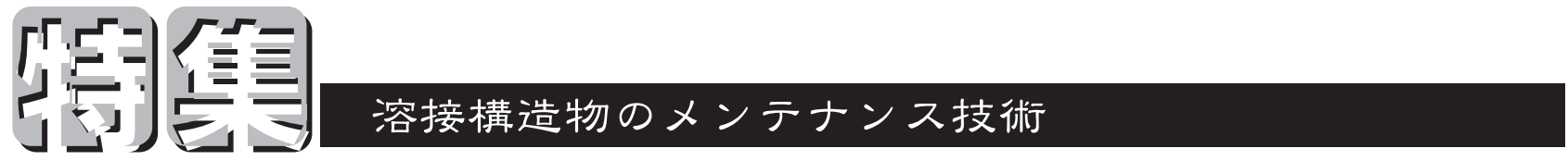

\title{
船舶におけるメンテナンス技術とその動向 ${ }^{*}$
}

\author{
松 本 俊 之 ${ }^{* *}$
}

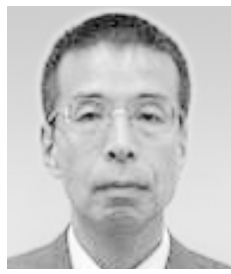

Recent Trend of Maintenance Technology of Ships ${ }^{*}$

by MATSUMOTO Toshiyuki $^{* *}$

キーワード メンテナンス，疲労，モニタリング

\section{1.はじめに}

多くの船舶は海上を航行し，物資や人間を輸送する。 そ の際，船体の傾き（トリム）等を調整するために, 船体構 造の一部に専用の海水タンク (バラストタンク)を有し, 適 宜海水を漲水する。このため, 他の構造物と比べ次のよう な保守管理上の特徵がある。

・厳しい腐食環境下で使用される

・波浪による不規則変動荷重を繰り返し受けるため, 船 体構造強度上, 疲労強度が重要な因子の一つとなる

本稿では, このうちの度労強度に関するメンテナンス技 術として, 疲労モニタリング技術の開発に関する取組みを 紹介する。

船体構造強度評価に抢いて, 疲労強度は降伏強度, 座屈 強度及び最終強度と並び重要な検討項目の一つである. 現 在, 船船は想定した就航期間 (一般商船の場合は通常25年) に対し，十分な疲労強度を有するように設計されている. しかしながら，

・設計時に想定した標準的な航路と実際に本船が航行 した航路が異なる場合

・想定以上に厳しい海象に遭遇した場合

・規則では想定していない荷重パターンを受ける場合 （例えば，短期間で荷役を繰り返すシャトルタンカー など)

・長期間（25年以上）に亘り運航する場合（LNG 船など の高付加価値船)

においては, 設計時の想定と実際の疲労の蓄積度合いの差 を把握する必要がある，そこで, 本船の疲労の蓄積度合い を把握するために用いられるのが, 疲労モニタリングであ る. 疲労モニタリングにより船体構造部材における疲労の

\section{*原稿受付 平成25年7月13日}

蓄積度合いを監視することができれば, 補強や切り替え工 事を実施する時期及び範囲などについて，合理的な保守管 理が可能になると期待される. また, 現状の疲労の蓄積度 合いが判明していれば，LNG 船などの高付加価值船の合 理的な延命対策も可能になると思われる.

本稿では, この疲労モニタリングに関する研究について紹 介する。

\section{2. 疲労及び度労モニタリング}

\section{1 疲労}

船舶は航行中，繰り返し波浪を受ける。これにより，船 体構造部材には繰り返し応力が作用する. 一つ一つの応力 は小さくても, 少しずつ目に見えないダメージ (疲労) が 船体構造部材に蓄積されていく.やがて, 蓄積した疲労は き裂（疲労損傷）を発生させ，船体構造部材の強度低下を 招く。このように，繰り返し応力が作用することにより船 体構造部材にき裂を生じさせ, 強度低下を招く現象を疲労 と呼ぶ.

通常, 疲労の蓄積度合いは目視で確認できない。それゆ え, 疲労モニタリングにより現在疲労がどの程度蓄積して いるかを把握することが重要となる.

\section{2 疲労モニタリング}

疲労モニタリングとは, 疲労の蓄積度合いを監視（モニ タリング) するシステムである. 疲労モニタリングの手法 は，以下のように大別できる.

a）モニタリングツールを使用し, 疲労の蓄積度合いを 推定する手法

b）本船の遭遇海象デー夕を基に疲労強度解析を実施 し，疲労の蓄積度合いを推定する手法

c）上記の a）及びb）を組み合わせた手法

どの疲労モニタリング手法を用いるかは, 船種, モニタ リング対象箇所数, 度労の蓄積度合いの推定精度, 費用, 定 
期的なデー夕回収法といった様々な因子を考慮のうえ, 適 切な手法を選択する。

\section{3 モニタリングッール}

モニタリングッールとは, 船体構造部材に作用する応力 の大きさ, 頻度に反応する機器で,

a) 犠牲試験片タイプ

b）歪ゲージや光ファイバー等を用いた応力頻度計測夕 イプ

に大別できる（図 1 ).

犠牲試験片タイプのモニタリングッールは一般的に薄 い金属片であり, 船体構造部材に溶接又は接着剂で取り付 けられる.そして, 犠牲試験片上に設けられた切り欠き又 は初期き裂から進展したき裂について, その進展量を基に 疲労の蓄積度合いを求める.

この犠牲試験片タイプのモニタリングッールの特徵は 以下の通りである。

・電源が不要である（配線工事が必要ない）

・ツール自体は比較的安価である

・き裂長さを計測するために, 作業員が直接設置箇所ま で赴く必要がある

・基本的に一定応力下での使用を前提としているため, 船舶特有のランダムな応力下での適用性を明確にす る必要がある

一方, 歪ゲージや光ファイバー等を用いた応力頻度計測 タイプのモニタリングツールは, 応力計測用の機器（歪ゲ ージや光ファイバー) と計測データを蓄える本体から成り 立ち, 船体構造部材に添付した計測用機器を介して作用応 力の大きさ及びその頻度を計測する.

この応力頻度計測タイプのモニタリングッールの特徴 は以下の通りである。

・電源又はバッテリーが必要である（配線工事や船種に よっては防爆処理が必要)

・配線工事などを含めると, 導入費用が掛かる

・データケーブル等を用いれば, 作業員が直接設置箇所 に赴かなくてもデータの回収ができる

・船舶に特有なランダムな応力にも適用できる

\section{3. 犠牲試験片タイプの疲労モニタリング ツール}

\section{1 犠牲試験片タイプの疲労モニタリングッール}

犠牲試験片タイプのモニタリングッールが本来対象と している応力履歴は, 図 2 (a) に示すような一定応力履歴 である.しかし, 船体構造部材に作用する応力は図 2 (b) に 示すような, 遭遇海象及び積付状態に応じて応力範囲及び 平均応力が変化する変動応力履歴である.

そこで, 犠牲試験片タイプのモニタリングツールを試験 体に取り付け, 実際の船体構造部材に生じる応力履歴を模 擬した荷重パターン（嵐モデル）と，線形累積被害則に基 づき嵐モデルと等価な疲労被害度を与える一定荷重パタ ーン (等価応力モデル)の下で, 平均応力を引張側 (50 MPa) 及び圧縮側 (-50 MPa) それぞれ 3 ケースで疲労試験を実施 した (図 3 ).
疲労試験結果を図 4 に示す. 図 4 において横軸が繰り返 しセット数（1 セット約 15,000 サイクル）を, 縦軸が犠牲 試験片上のき裂進展量を示している。（いずれも 3 ケース の平均を図示).

このような疲労試験を様々に実施し, 犠牲試験片タイプ のモニタリングッールを船体構造部材に適用する場合の 修正係数を提案した6).

\section{2 実船への試適用}

各種モニタリングッールを LNG 船, コンテナ運搬船, 鉱
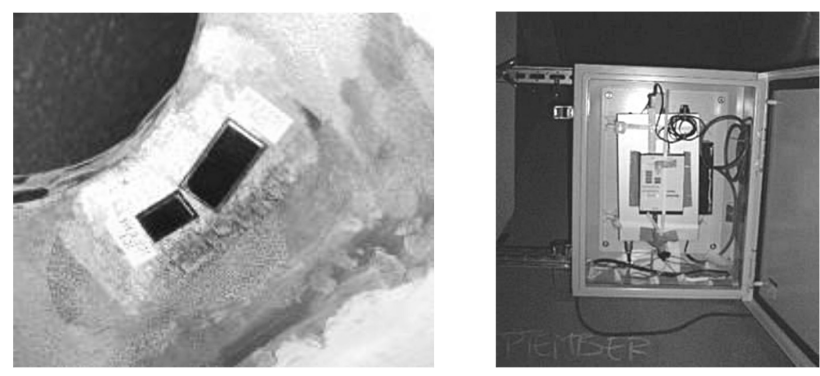

図 1 モニタリングツールの一例 ( $\mathrm{a}$ ：犠牲試験片, b : 応力頻度 計測器)

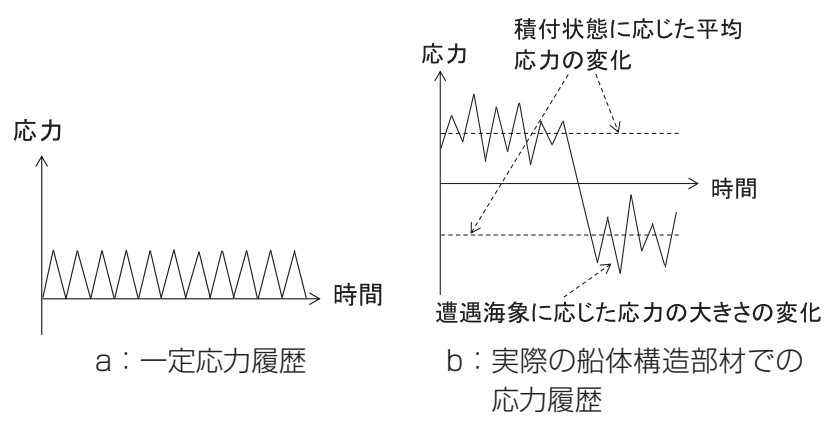

図 2 応力履歴

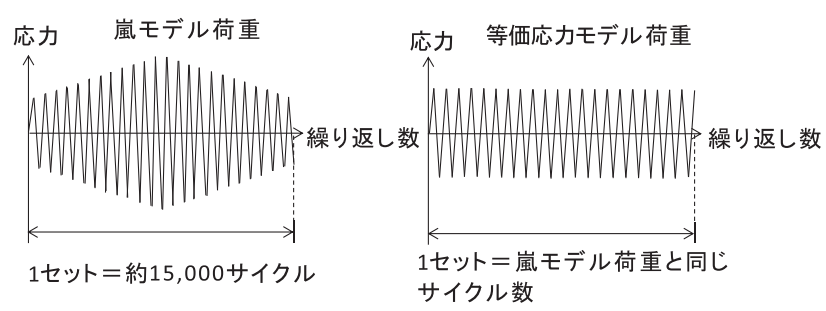

図 3 荷重モデル

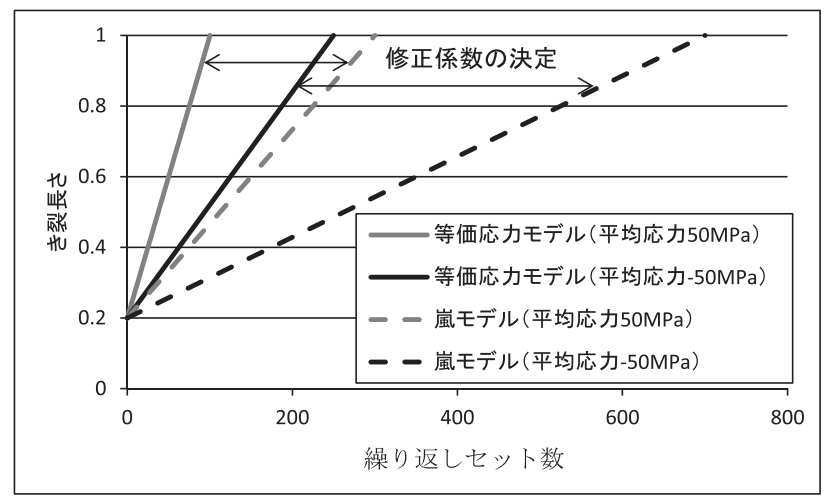

図 4 疲労試験結果 

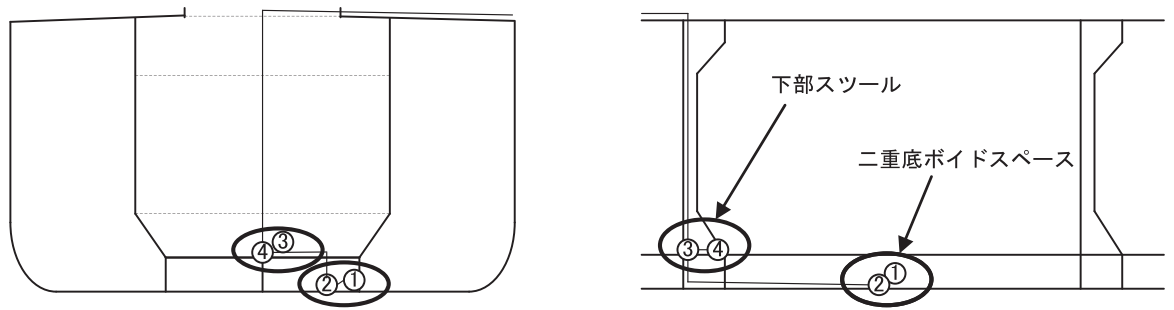

図 5 モニタリングツールの設置位置

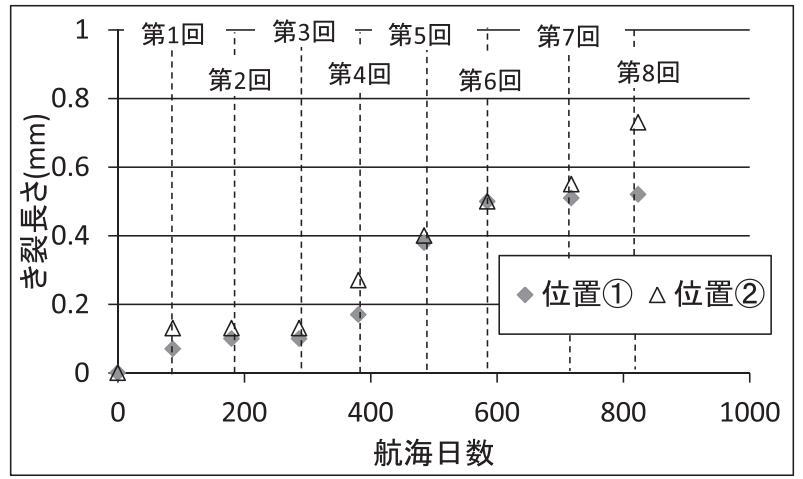

図 6 二重底ボイドスペースにおける犠牲試験片上のき裂進展量

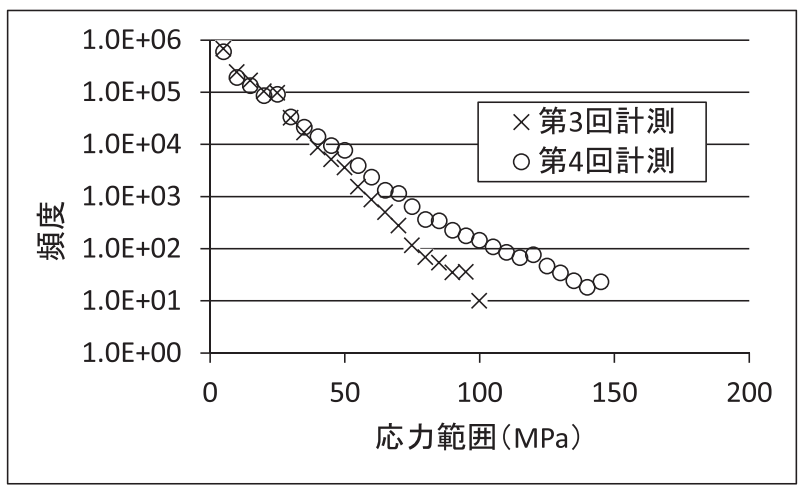

図 7 二重底ボイドスペースにおける応力頻度計測結果

石運搬船及び油タンカー等に対し試適用した。そしてモニ タリングデー夕を定期的に回収し, 疲労の蓄積度合いの推 定を実施した。ここでは, 船の長さ $318 \mathrm{~m}$ の鉱石運搬船の 例を示す。計測期間は2009年から2011年で, 航路は日本一 ブラジルである。なお，デー夕の回収は 8 回行われた.

モニタリングッールは船体中央部に扔ける二重底ボイ ドスペース及び下部スッール内のそれぞれ 2 箇所に設置 した（図 5 ).

計測結果の一例として, 二重底ボイドスペースにおける 計測結果を図 6 及び図 7 に示す. 図 6 は犠牲試験片上のき 裂進展量を示し, 図 7 は応力頻度計測結果を示している. 図 6 より, き裂進展量は計測時期により大きく異なること が分かる. また同様に，図 7 より応力頻度分布も計測時期 により異なることが分かる。この計測結果より，遭遇海象 に応じて疲労の蓄積度合いが異なるという現象をモニ夕 リングッールにより把握できることが確認された。

また，実船への試適用を通じて判明したのが，「作業員が 陸上から本船に乗船してデータを回収するシステムの場

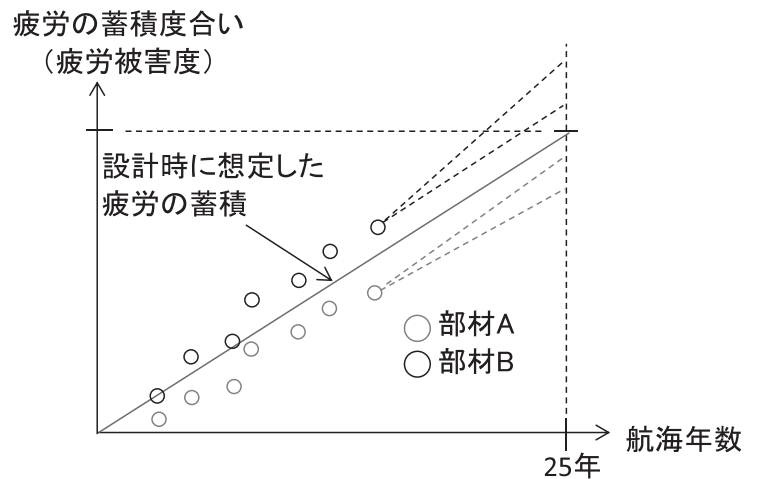

図 8 疲労の蓄積の様子

合，本格的な疲労モニタリングの運用を行うことは難し い」ということである.すなわち,

・日本に寄港しない航路の場合, 海外で作業員がデー夕 の回収を行う必要がある

・多数の船舶で同時にモニタリングを行う場合, 作業員 の確保が難しくなる

からである。

\section{4. 疲労モニタリングシステムの構築}

設計時における疲労強度評価からモニタリング箇所の 選定, 就航後の定期点検まで一貫した評価システムの構築 に関する検討を行った. 疲労モニタリングの流れを以下に 示す.

(1)疲労強度解析及び過去の損傷事例に基づき, 疲労強度 上危険な箇所をリストアップする.

(2)疲労モニタリングの手法を決定する.

(3)損傷時の重大さ, アクセスの容易さ等を考慮してモニ タリング対象筒所を決定する。

(4)疲労モニタリングッールを設置する.

(5)就航後，定期的にデータの回収作業を実施する.

(6)疲労の蓄積度合いを推定する.

(7)本船の保守, 管理計画に疲労蓄積推定結果を反映さ せる。

これらの項目について, 順次説明していく.

4.1 疲労モニタリング対象箇所のリストアップ

設計海域及び設計寿命を定めて疲労強度解析を実施す るとともに, 過去の損傷事例を考慮して疲労モニタリング の対象候補箇所をリストアップする。

4.2 疲労モニタリングの手法決定

船種, モニタリング対象箇所数, 疲労の蓄積度合いの推 
定精度, 費用, 定期的なデータの回収法等の様々な因子を 考慮して，適切な手法を選択する.

a）モニタリングツールの使用

b）遭遇海象データから疲労の蓄積度合いを推定

c）上記 a）及びb）の組み合わせ

なお，b）の手法では，遭遇海象データを，

・航海日誌や気象情報を基に推測する

・加速度や傾斜角といった船体運動を計測し，そのデー 夕を基に船体運動解析を実施して推測する

といった方法が考えられる。そして, 推測した遭遇海象デ 一夕を基に疲労強度解析を実施し, 疲労の蓄積度合いを推 定する。

\section{3 疲労モニタリング対象箇所の決定}

損傷時の重大さ，アクセスの容易さ等を考慮してモニタ リング対象箇所を決定する。しかしながら，リストアップ された全ての危険箇所にモニタリングッールを設置でき るわけではない. なぜなら, 設置工事及びデー夕回収に掛 かる費用及び手間が膨大になるからである.

そこで, 以下の基準を基にモニタリング対象箇所を決定 する。

・疲労損傷が生じると船体構造に致命的な影響を与え る箇所

・疲労強度上危険な箇所のうち, モニタリングッールの 設置工事及びデー夕回収が容易な箇所

・上記箇所が多数ある場合には代表的な箇所を選ぶ

・モニタリングッールを設置しない箇所については, 疲 労強度解析結果に基づきモニタリングッールを設置 した箇所との相対評価を行う

\section{4 モニタリングデータの回収}

就航後, 定期的にモニタリングデータを回収することに なる. 試適用では作業員が陸上から本船に乗船してデー夕 の回収を行っていた。しかし，日本に寄港しない船舶で疲 労モニタリングを実施する場合, 又は同時に多数の船舶に 対して疲労モニタリングを実施する場合のことを考慮す ると, 本船乗組員の手でデータの回収を行えるシステムが 望ましい。

\section{5 疲労の蓄積度合いの推定及び保守管理計画への 反映}

犠牲試験片タイプのモニタリングツールの場合は, 犠 牲試験片上のき裂長さから現時点での疲労被害度を換算 する。
一方, 応力頻度計測タイプのモニタリングッールの場合 は, 得られた応力頻度分布を用い, 船級協会の疲労強度評 価手法に則り疲労被害度を算出する.

現在までの疲労の蓄積傾向から将来の疲労の蓄積度合 いを推定し, 今後の保守管理計画に反映させる. 図 8 に疲 労モニタリング結果から疲労の蓄積度合いを推定した結 果の模式図を示す。

\section{5. まとめ}

以上, 犠牲試験片タイプの疲労モニタリングを用いたよ り合理的な船舶の保守管理の可能性について, これまでの 試みを中心に述べてきたが, 犠牲試験片タイプの疲労モニ タリングは, 特にデータの収集という点において実用上の 問題がある. 今後は, 歪ゲージや光ファイバー等による応 力モニタリングとの併用や, 事前の構造解析により波浪荷 重と船体構造応答との関係を把握しておき, それとの関係 付けでより合理的かつ実際的なモニタリングデータの活 用を考えるなどの検討が, 疲労強度モニタリングの実用化 及びそれの船体メンテナンスへの実際的な活用において は，重要と考える。

\section{参考文献}

1) 山本規雄, 他 : 実船の応力計測と儀牲試験片観察, 平成18年 度日本船舶海洋工学会東部支部春季講演会, 2006 .

2) 山本規雄：船舶の疲労寿命の予測方法, 日本海事協会会誌 第 278 号, 2006.

3）高野裕文, 他：疲労センサを使用した LNG 船の疲労強度管 理システム, JCOSSAR2007 第 6 回構造物の安全性・信頼 性に関する国内シンポジウム，2007.

4) 山本規雄, 他：疲労センサを応用した船体寿命監視システ 厶，日本海事協会会誌第 282 号，2007.

5) 山本規雄 : 船舶の Total Life Assessment, 溶接学会誌 Vol.77, 2008.

6）孝岡祐吉，他：疲労センサを用いた船体構造の疲労寿命推 定精度向上について, 日本船舶海洋工学会, 平成 20 年度秋季 講演会, 2008 .

7）山本規雄：船体構造の寿命に大きな影響を及ぼす疲労・腐 食問題及び管理，日本鉄鋼協会会誌 Vol.13，2008.

8）技術研究所：LNG 船の生涯に亘るトータルサポートシス テムの開発, 日本海事協会会誌第 288 号, 2009.

9）技術研究所：疲労余寿命評価に基づく就航中管理に関する 研究, 日本海事協会会誌第 295 号, 2011. 